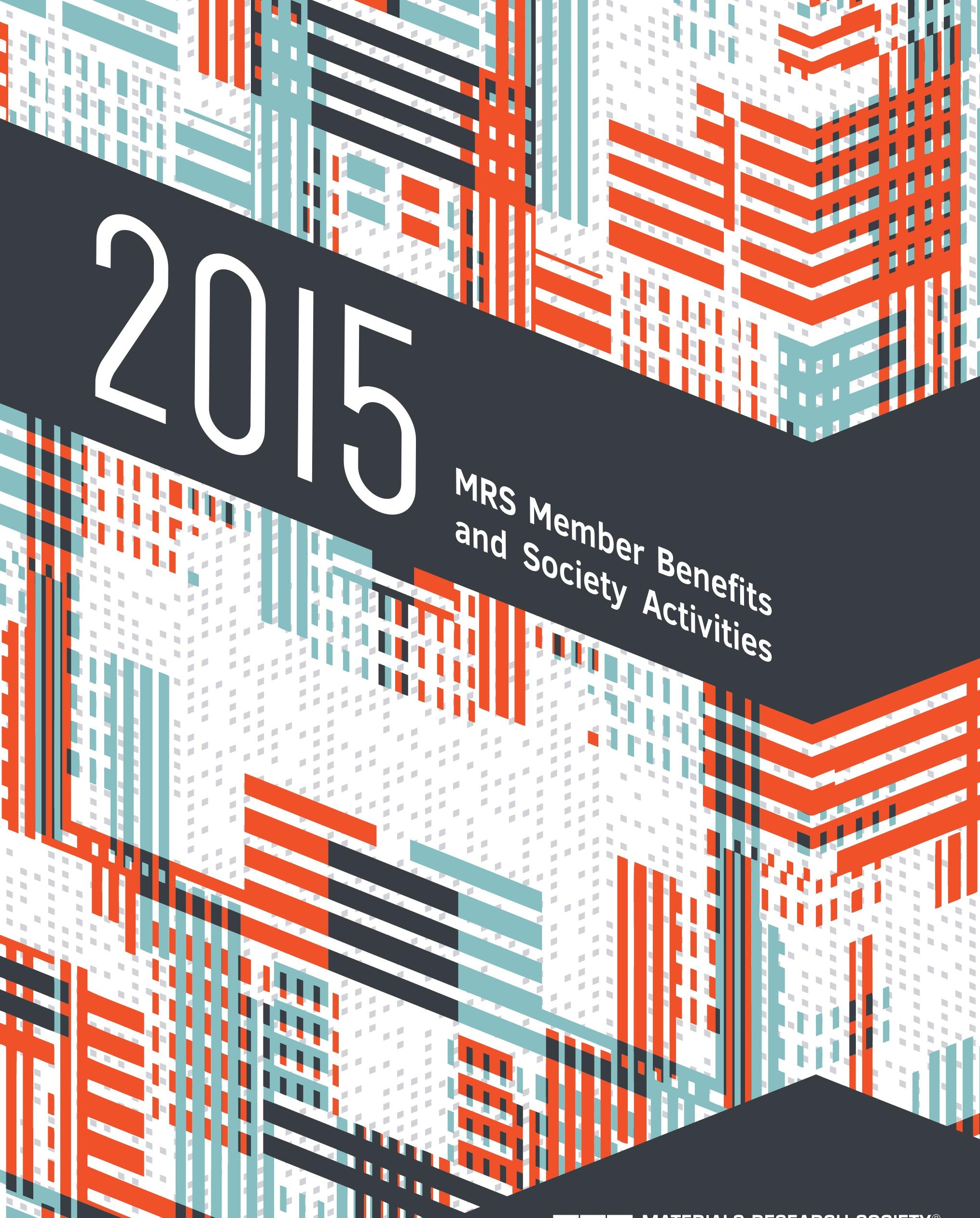




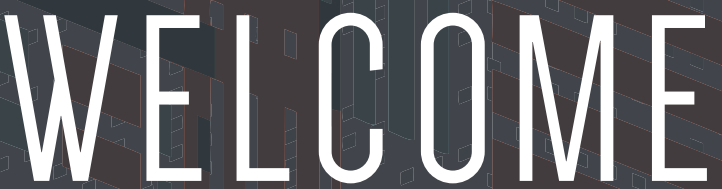

to the Materials Research Society

MRS is a growing, vibrant, member-driven organization focused on broadening the impact of materials science and improving the quality of life. Our members are research professionals from industry, academia and government from around the world, and they choose MRS because it is important to their work and careers.

As a member, you will enjoy the many benefits MRS has to offer-subscription to the online letters and prospectives journal, MRS Communications; a print and electronic subscription to MRS Bulletin; access to the MRS Online Proceedings Library, which now includes over 100,000 proceedings papers; access to Materials360 Online, our news resource designed specifically for the materials research community; listing in, and access to, the online MRS Member Directory; discounted rates for MRS meetings and workshops, to name just a few.

New for 2015, MRS members will receive free access to MRS Energy \& Sustainability-A Review Journal, focused on key topics in materials research and development as they relate to energy and sustainability. Also look forward to the continued growth and expansion of MRS OnDemand ${ }^{\circledR}$. Increased capabilities have allowed live-streaming and electronic capture of more content, benefiting on-site and remote attendees both during, and after, MRS Meetings.

What you might not know about MRS is that we are expanding our professional development portfolio to better meet your career needs and to better serve the materials research community. These efforts include:

- advocating for increased and sustained funding for the physical sciences

- fostering outreach and science education for policy leaders and the general public

- promoting diversity and inclusion in the scientific workforce

- introducing prestigious new awards

- collaborating with international partners on bilateral projects

By joining MRS, you add your voice to those of over 16,000 others who support these efforts and believe in the MRS mission of advancing interdisciplinary materials research to improve the quality of life.

wwW.mrs.org
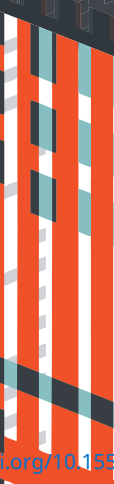
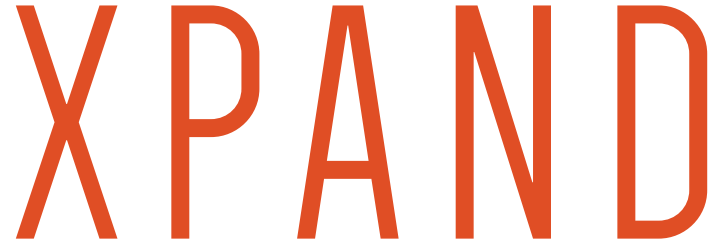

\section{YOUR KNOWLEDGE}

The full suite of MRS publications-MRS Communications, MRS Bulletin, Journal of Materials Research, the MRS Online Proceedings Library and the new MRS Energy \& Sustainability - A Review Journal-is hosted on Cambridge Journals Online (CJO). For both authors and readers that means expanded benefits ... advanced search capabilities, reference linking, mobile browser accessibility and more! An Open Access option is available for select MRS Publications at discounted rates through 2015; MRS members enjoy additional discounts.

\section{MRS ENERGY@ SUSTAINABILITY A Review Journal}

Now available, MRS Energy \& Sustainability - A Review Journal is FREE to MRS Members and publishes reviews on key topics in materials research and development as they relate to energy and sustainability.

Review topics include new R\&D of both established and new areas; interdisciplinary systems integration; and objective application of economic, sociological and governmental models, enabling research and technological developments. Reviews will be set in an integrated context of scientific, technological and sociological complexities relating to environment and sustainability.

The intended readership is a broad spectrum of scientists, academics, policymakers and industry professionals, all interested in the interdisciplinary nature of the science, technology and policy aspects of energy and sustainability.

Open Access option available.

\section{www.mrs.org/energy-sustainability-journal}

\section{MRS OnInePROCEEDINGS LIBRARY}

The MRS Online Proceedings Library (OPL), FREE to all MRS members, offers unlimited full-text availability to over 100,000 papers from the well-recognized MRS Symposium Proceedings Series-proceedings published from Volume 1 to the present, with more added daily. The collection also includes many proceedings papers that were never published in print format and are available only online.

This massive database is an ideal reference for graduate students, corporate scientists and engineers, and overseas researchers needing access to current information without the lag time of printing and mail delivery.

For our more archivally minded members, print volumes of the MRS proceedings are available at $15-20 \%$ off list price.

\section{www.mrs.org/opl}




\section{Books and Textbooks from the Materials Research Society and Cambridge University Press}

MRS continues to expand the breadth and scope of its Book Collection. Leading experts from around the world provide comprehensive coverage of topics spanning physics, chemistry, biology, mathematics and engineering - the full spectrum of materials research. MRS members receive special discounted pricing on all MRS books and textbooks. Visit www.mrs.org/books-textbooks for the latest offerings in the Collection.
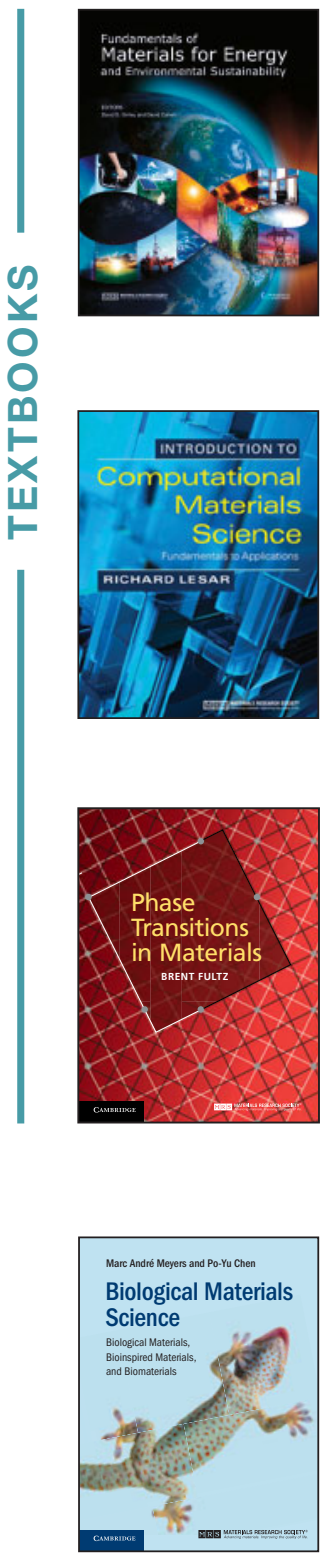

Fundamentals of Materials for Energy and Environmental Sustainability

EDITORS: David S. Ginley and David Cahen ISBN: 9781107000230

List Price: $\$ 110.00$

MRS Member Discount Price: $\$ 88.00$

A unique, interdisciplinary textbook with contributions from more than 100 experts in energy and the environment from around the world.

www.cambridge.org/ginley

Introduction to Computational Materials Science Fundamentals to Applications

AUTHOR: Richard LeSar

ISBN: 9780521845878

List Price: $\$ 100.00$

MRS Member Discount Price: $\$ 80.00$

Emphasizing essential methods and universal principles, this textbook provides everything students need to understand the basics of simulating materials behavior.

www.cambridge.org/lesar

Phase Transitions in Materials

\section{AUTHOR: Brent Fultz}

ISBN: 9781107067240

List Price: $\$ 90.00$

MRS Member Discount Price: $\$ 72.00$

Offering a fresh viewpoint on phase changes and the thermodynamics of materials, this textbook covers the thermodynamics and kinetics of the most important phase transitions in materials science, spanning classical metallurgy through to nanoscience and quantum phase transitions. www. cambridge. org/fultz

\section{Biological Materials Science}

Biological Materials, Bioinspired Materials, and Biomaterials

AUTHORS: Marc André Meyers and Po-Yu Chen ISBN: 9781107010451

List Price: $\$ 99.00$

MRS Member Discount Price: $\$ 79.00$

Split into three sections-Basic Biology Principles, Biologica Materials, and Bioinspired Materials and Biomimetics-this book presents biological materials along with the structural and functional classification of biopolymers, bioelastomers, foams, and ceramic composites.

www.cambridge.org/bms

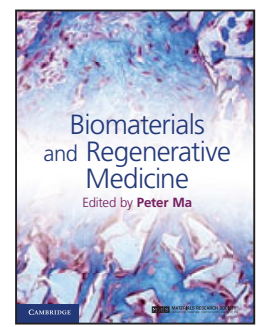

Biomaterials and Regenerative Medicine

EDITOR: Peter Ma

ISBN: 9781107012097

List Price: $\$ 185.00$

MRS Member Discount Price: $\$ 148.00$

Emphasizing basic principles and methodology, this book covers stem cell interactions, fabrication technologies, design principles, physical characterization and biological evaluation, across a broad variety of systems and biomaterials.

www.cambridge.org/biomaterials

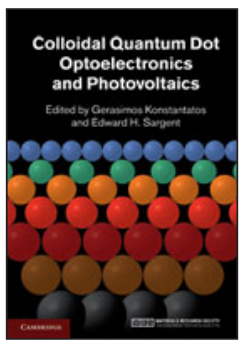

Colloidal Quantum Dot Optoelectronics and Photovoltaics

EDITORS: Gerasimos Konstantatos and Edward H. Sargent ISBN: 9780521198264

List Price: $\$ 130.00$

MRS Member Discount Price: $\$ 104.00$

Written in an accessible style by the world's leading experts, this book captures the most up-to-date research in colloidal quantum dot devices.

www.cambridge.org/colloidal

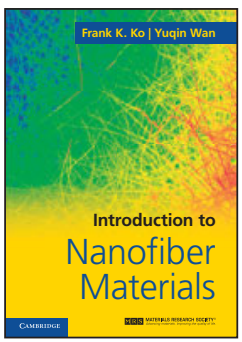

\section{Introduction to Nanofiber Materials}

AUTHORS: Frank K. Ko and Yuqin Wan

ISBN: 9780521879835

List Price: $\$ 99.00$

MRS Member Discount Price: $\$ 79.00$

Presenting the latest coverage of the fundamentals and applications of nanofibrous materials and their structures for graduate students and researchers, this book bridges the communication gap between fiber technologists and materials scientists and engineers.

www.cambridge.org/nanofiber

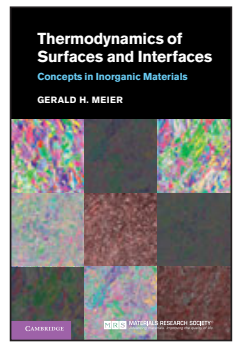

Thermodynamics of Surfaces and Interfaces Concepts in Inorganic Materials

AUTHOR: Gerald H. Meier

ISBN: 9780521879088

List Price: $\$ 120.00$

MRS Member Discount Price: $\$ 96.00$

This book provides an accessible yet rigorous discussion of the thermodynamics of surfaces and interfaces, delivering a comprehensive guide without an overwhelming amount of mathematics.

www. cambridge.org/meier 


\section{GAIN RECOGNITION}
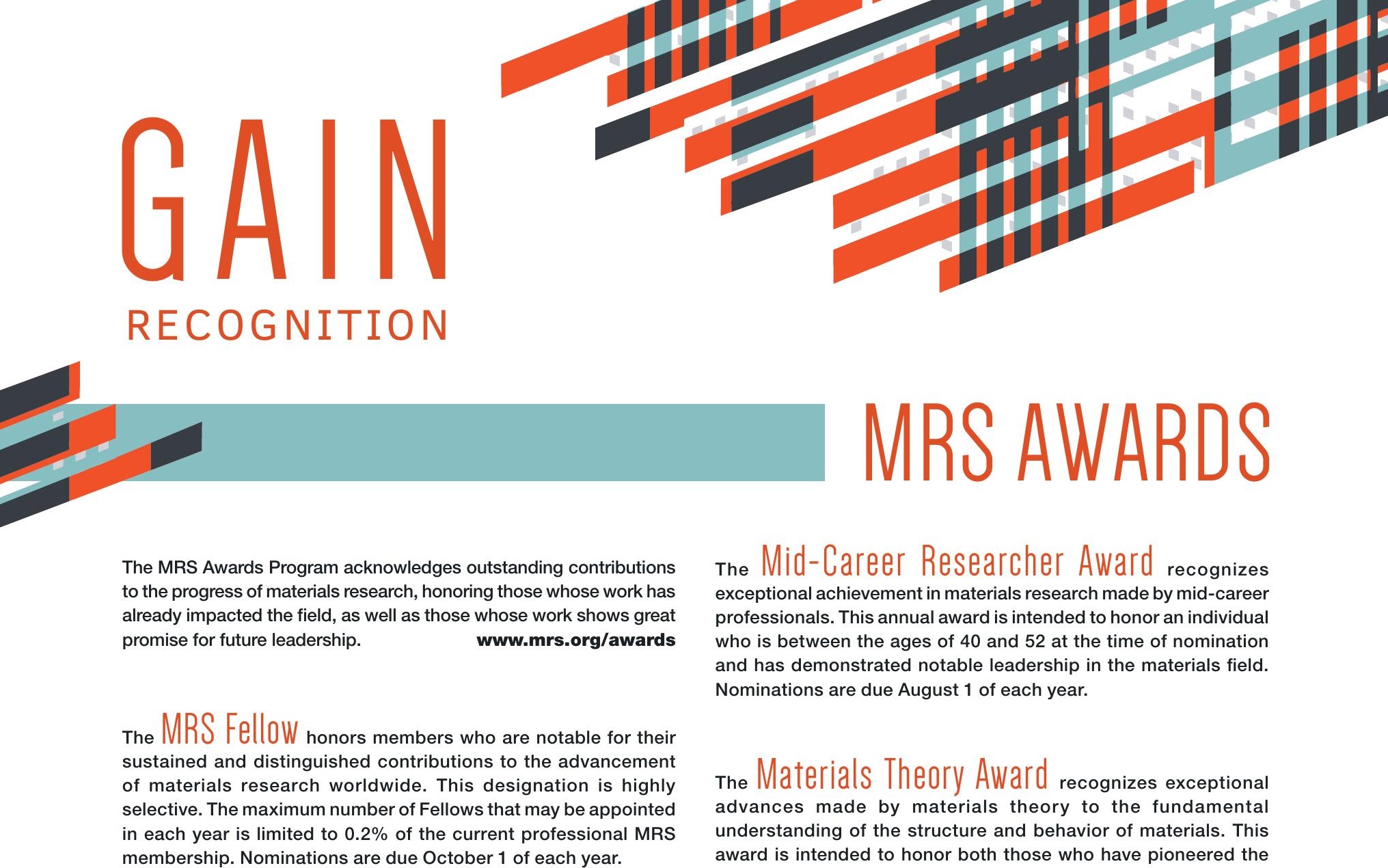

membership. Nominations are due October 1 of each year.

The Von Hippel Award is the Materials Research Society's highest honor and recognizes those qualities most prized by materials scientists and engineers-brilliance and originality of intellect, combined with vision that transcends the boundaries of conventional scientific disciplines. Nominations are due April 1 of each year.

The David Turnbull Lectureship Award recognizes the career of a scientist who has made outstanding contributions to understanding materials phenomena and properties through research, writing and lecturing, as exemplified by the life work of David Turnbull. Nominations are due April 1 of each year.

The MRS Medal recognizes an exceptional recent achievement in materials research that is expected to have a major impact on the progress of any materials-related field. Nominations are due April 1 of each year.

The Innovation in Materials Characterization Award honors an outstanding advance in materials characterization that notably increases our knowledge of the structure, composition, in situ behavior under outside stimulus, electronic, mechanical, or chemical behavior, or other characterization feature, of materials. Nominations are due August 1 of each year.

The Mid-Career Researcher Award recognizes exceptional achievement in materials research made by mid-career professionals. This annual award is intended to honor an individual who is between the ages of 40 and 52 at the time of nomination and has demonstrated notable leadership in the materials field. Nominations are due August 1 of each year.

The Materials Theory Award recognizes exceptional advances made by materials theory to the fundamental understanding of the structure and behavior of materials. This award is intended to honor both those who have pioneered the development of a new theoretical approach and those who have used existing approaches to provide significant new insight into materials behavior. Nominations are due April 1 of each year.

The Outstanding Young Investigator Award recognizes outstanding, interdisciplinary scientific work in materials research by a young scientist or engineer. The award recipient must also show exceptional promise as a developing leader in the materials area. Nominations are due August 1 of each year.

MRS Graduate Student Awards nonor and encourage graduate students whose academic achievements and current materials research display a high order of excellence and distinction. Finalists compete for Gold and Silver Awards at the MRS Spring and Fall Meetings. Applications are due approximately five months preceding each MRS Meeting.

The Arthur Nowick Graduate Student Award, which honors the late Dr. Arthur Nowick and his lifelong commitment to teaching and mentoring students in materials science, recognizes a Graduate Student Award finalist who shows particular promise as a future teacher and mentor. This award is presented at each Fall Meeting. 


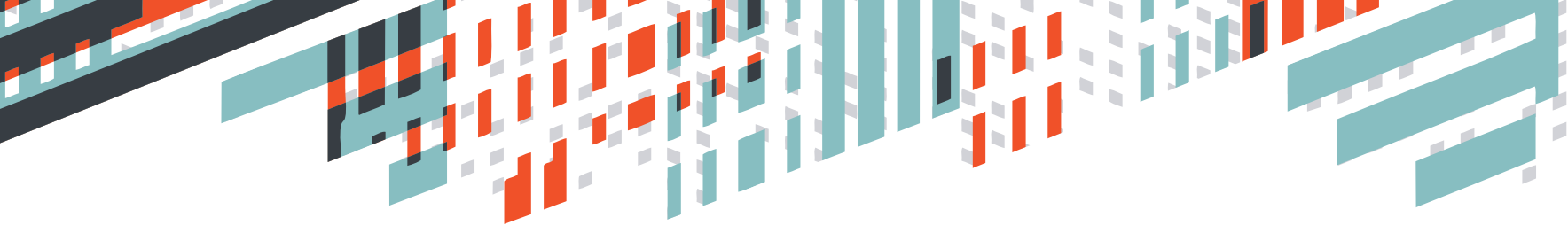

\section{NEW AWARDS}

The MRS Postdoctoral AWards recognize postdoctoral scholars who are showing exceptional promise that may include, for example, excellence in scientific research, leadership, advocacy, outreach, or teaching, during their postdoc assignment.

sponsored by The Kavli Foundation, the Kavli Early Career Award in Nanoscience recognizes an early-career person whose research is important to nanoscience.

\section{Publishing Opportunities}

Publishing venues for MRS members include MRS Communications, MRS Bulletin, Journal of Materials Research (JMR), MRS Energy \& Sustainability $-A$ Review Journal and the MRS Online Proceedings Library (OPL). To propose a theme topic for MRS Bulletin, or for information on guest-editor opportunities, contact the Bulletin editor at rao@mrs.org. Authors wishing to submit to JMR should visit www.mrs.org/jmr for complete author instructions.

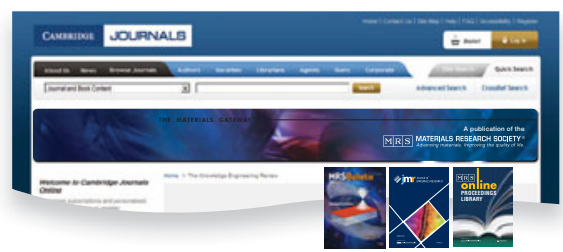

For information about submitting to $M R S$ Communications, visit www.mrs.org/mrc. To submit a proposal to the new MRS Energy \& Sustainability-A Review Journal, visit www. $\mathrm{mrs}$.org/energy-sustainability-journal. To propose new books or other publications, contact the Principal Development Editor at fleisher@mrs.org.

In addition, the $O P L$ offers opportunities to publish papers presented at MRS Meetings and other scientific and technical meetings.

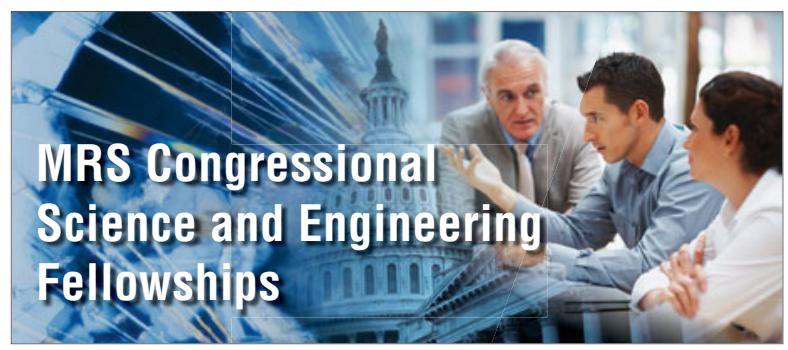

Decisions made by Congress, regulatory agencies and local government have profound effects on the way in which science is conducted. By keeping decision makers well informed on the current affairs of the scientific community, MRS Congressional Science and Engineering Fellows ensure the right choices are being made. Now's your time to make a difference!

The Materials Research Society offers materials scientists two exciting opportunities to participate in, and contribute to, the federal policymaking process, while learning firsthand about the intersection of science and policy.

During your year as a Fellow you will:

- be placed in a specific congressional office to serve as an advisor on science-related issues

- contribute widely to the effective use of materials science knowledge in government

- broaden awareness about the value of scientist- and engineer-government interaction among society members and within government

- network with more than 250 other participants of science and technology fellowship programs

- have significant freedom to follow specific topics and issues that interest you

Information and application deadlines may be found online.

www.mrs.org/congressional-fellows 
MRS Membership Rates

$\square$ I am a new member

$\square$ Please renew my membership

Rates are for 12 months and include complimentary subscriptions to MRS Bulletin, MRS Communications, MRS Online Proceedings Library, and MRS Energy \& Sustainability $-A$ Review Journal.

Begin Membership: $\quad \square$ January 1, $2015 \quad \square$ July 1, 2015

$\begin{array}{lcc}\text { Regular Membership } & \$ 125.00 & \$ \\ \text { Includes MRS Bulletin in all access formats. } & \\ \text { * Student Membership } & \$ 30.00 & \$ \\ \begin{array}{l}\text { Includes MRS Bulletin in all access formats except print. } \\ \text { Retired }\end{array} & \$ 40.00 & \$ \\ \begin{array}{l}\text { Includes MRS Bulletin in all access formats. } \\ \text { Unemployed }\end{array} & \$ 30.00 & \$\end{array}$

Includes MRS Bulletin in all access formats.

* NEW-FREE electronic membership available for qualified students in developing countries. Visit www.mrs.org/dev-countries-member to learn if you are eligible and how to apply.

Add a subscription to Journal of Materials Research (JMR).

Subscription will begin on membership date.

All subscription options to JMR include online access

to full-text articles from January 1986 to the current issue!

\begin{tabular}{lll} 
Member Subscription - online only & $\$ 100.00$ & $\$$ \\
$\begin{array}{l}\text { Member Subscription - print and online } \\
\text { North America }\end{array}$ & $\$ 260.00$ & $\$$ \\
Rest of World & $\$ 334.00$ & $\$$ \\
\hline ubtotal & & $\$$
\end{tabular}

\section{Materials Research Society Foundation (optional)}

Donations to the Materials Research Society Foundation support the MRS mission, encouraging scientific study and innovationand allow MRS to enhance and extend its awards, honors, education and outreach programs, as well as fund new member-driven grassroots projects.

I am pleased to support the Materials Research Society Foundation.
$\square \$ 10$
$\square \$ 25$
$\square \$ 50$
$\square$ Other

$\square$ I would like my donation to be anonymous

\section{Contribution Options:}

$\square$ Education and Outreach Programs

$\square$ University Chapter Special Projects

$\square$ Graduate Student Awards

Unless specifically designated above, your contribution

will be used for MRS Education and Outreach Programs.

The Materials Research Society Foundation operates as a program of the Materials Research Society. The officia registration and financial information of the Materials Research Society Foundation may be obtained from the Pennsylvania Department of State by calling toll free, within Pennsylvania, 1.800.732.0999. Registration does not imply endorsement.

\section{Payment Information}

\section{$\gg$ ENTER PAYMENT TOTAL HERE: \$}

$\square$ Check/money order enclosed-payable to Materials Research Society $\square$ Bill my credit card:
$\square$ MasterCard
$\square$ VISA
$\square$ American Express

\section{Exp. Date}

\section{Signature}

Mail or Fax

Materials Research Society

506 Keystone Drive

Warrendale, PA 15086 USA

Tel 724.779.3003

Fax 724.779.4732

Join/Renew Online

www.mrs.org/join

\section{Billing \& Shipping Address}

Name: First Middle Last

Membership ID\# (if renewing)

\begin{tabular}{ll}
\hline Institution & Dept./Mail Stop \\
\hline P.O. Box & Street \\
\hline Postal Code & City \\
\hline State/Province & Zip \\
\hline Tel: Country Area/City Local Number & Fax: CountryArea/City Local Number
\end{tabular}

Email address

Note: The address above will also be used in future MRS Member Directories unless you request an alternate address for the Directory.

\section{Student Applicants}

I am currently enrolled as a full-time student, or I am working full-time on a thesis or dissertation.

Signature

Date

\section{Member Demographics (optional)}

\section{Current Employment Status}

$\square$ Employed

$\square$ Student

$\square$ Retired

$\square$ Unemployed

Highest Level of Education

Doctorate degree/equivalent

$\square$ Master's degree /equivalent

$\square$ Bachelor degree/equivalent

$\square$ High school graduate/equivalent

$\square$ Other

\section{Year of Highest University Degree Earned}

$\square$

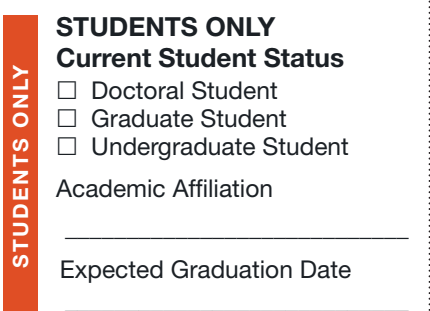

\section{Institution Type}

Indicate primary (1) and/or secondary (2). $\square$ Academic

$\square$ Industry

$\square$ Government/Military

$\square$ Non-Profit/Professional Association

$\square$ Other

\section{Title/Job Function}

$\square$ Student

$\square$ Postdoc

$\square$ Scientist/Engineer

$\square$ Professor

$\square$ Department Chair

$\square$ Executive/Management

$\square$ Sales/Marketing

$\square$ Press

$\square$ Retired

$\square$ Other

\section{Gender}

$\square$ Male $\square$ Female

Race/Ethnic Origin

$\square$ Asian

$\square$ Black or African Descent

$\square$ Hispanic

$\square$ Native American or Alaskan

$\square$ Native Hawaiian or Pacific Islander

White (Caucasian)

$\square$ Other

International Members Only Do you belong to a group (ethnic, gender, or other) that is considered underrepresented in the fields of Materials Science and Engineering (including Physics, Chemistry, Engineering) in your country?

$\square$ Yes $\square$ No

If yes, please specify your underrepresented group 


\section{Recent Titles}

from the Materials Research Society and Cambridge University Press

\section{Book Collection}

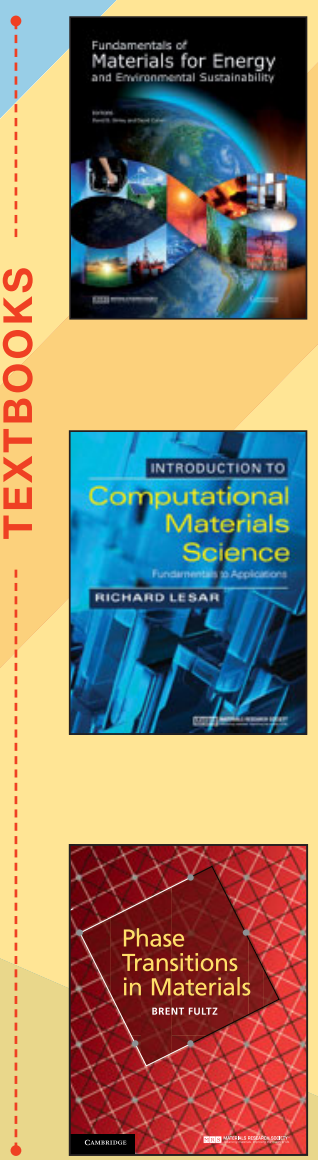

Fundamentals of Materials for Energy and Environmental Sustainability

EDITORS: David S. Ginley and David Cahen

ISBN: 9781107000230

List Price: $\$ 110.00$

MRS Member Discount Price: $\$ 88.00$

A unique, interdisciplinary textbook with contributions from more than 100 experts in energy and the environment from around the world.

www.cambridge.org/ginley

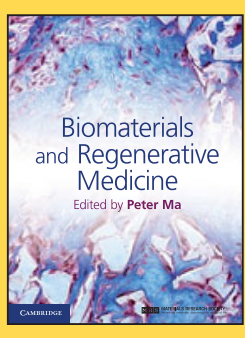

Introduction to Computational Materials Science Fundamentals to Applications

AUTHOR: Richard LeSar

ISBN: 9780521845878

List Price: $\$ 100.00$

MRS Member Discount Price: $\$ 80.00$

Emphasizing essential methods and universal principles, this textbook provides everything students need to understand the basics of simulating materials behavior

www.cambridge.org/lesar

Phase Transitions in Materials

AUTHOR: Brent Fultz

ISBN: 9781107067240

List Price: $\$ 90.00$

MRS Member Discount Price: $\$ 72.00$

Offering a fresh viewpoint on phase changes and the thermodynamics of materials, this textbook covers the thermodynamics and kinetics of the most important phase transitions in materials science, spanning classical metallurgy through to nanoscience and quantum phase transitions.

www. cambridge.org/fultz

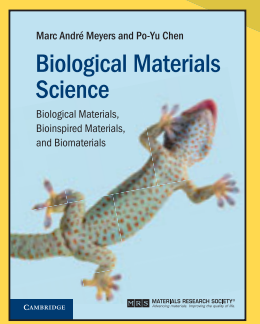

Biological Materials Science

Biological Materials, Bioinspired Materials, and Biomaterials

AUTHORS: Marc André Meyers and Po-Yu Chen ISBN: 9781107010451

List Price: $\$ 99.00$

MRS Member Discount Price: $\$ 79.00$

Split into three sections-Basic Biology Principles, Biological Materials, and Bioinspired Materials and Biomimetics-this book presents biological materials along with the structural and functional classification of biopolymers, bioelastomers, foams, and ceramic composites.

www.cambridge. org/bms

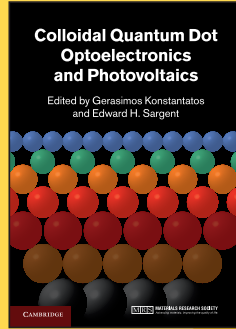

Biomaterials and Regenerative Medicine EDITOR: Peter Ma ISBN: 9781107012097

List Price: $\$ 185.00$

MRS Member Discount Price: $\$ 148.00$

Emphasizing basic principles and methodology, this book covers stem cell interactions, fabrication technologies, design principles, physical characterization and biological evaluation, across a broad variety of systems and biomaterials.

www. cambridge.org/biomaterials

Colloidal Quantum Dot Optoelectronics and Photovoltaics

EDITORS: Gerasimos Konstantatos and Edward H. Sargent ISBN: 9780521198264

List Price: $\$ 130.00$

MRS Member Discount Price: $\$ 104.00$

Written in an accessible style by the world's leading experts, this book captures the most up-to-date research in colloidal quantum dot devices

www. cambridge.org/colloidal

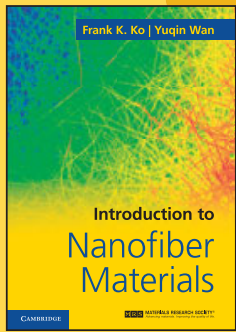

Introduction to Nanofiber Materials AUTHORS: Frank K. Ko and Yuqin Wan ISBN: 9780521879835

List Price: $\$ 99.00$

MRS Member Discount Price: $\$ 79.00$

Presenting the latest coverage of the fundamentals and applications of nanofibrous materials and their structures for graduate students and researchers, this book bridges the communication gap between fiber technologists and materials scientists and engineers.

www.cambridge.org/nanofiber

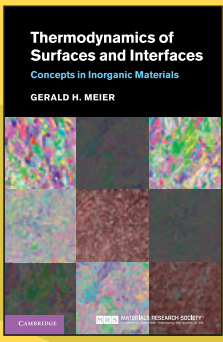

Thermodynamics of Surfaces and Interfaces Concepts in Inorganic Materials

AUTHOR: Gerald H. Meier

ISBN: 9780521879088

List Price: $\$ 120.00$

MRS Member Discount Price: $\$ 96.00$

This book provides an accessible yet rigorous discussion of the thermodynamics of surfaces and interfaces, delivering a comprehensive guide without an overwhelming amount of mathematics.

www.cambridge.org/meier
Enter Discount Code MRSMEMBER at checkout to apply the MRS Member discount.

Not an MRS Member? Join today at www.mrs.org/join. 